\title{
COMPARATIVE EFFICACY AND SAFETY OF PREVENTIVE TREATMENT WITH CYTOVIR-3 AND ARBIDOL IN CHILDREN DURING SEASONAL OUTBREAK OF RESPIRATORY VIRAL INFECTION (AN OPEN-LABEL RANDOMIZED CLINICAL STUDY)
}

\author{
V.S. Smirnov ${ }^{a}$, S.A. Savelyeva, S.V. Petlenko ${ }^{a}$, G. Redlich ${ }^{c}$, M.K. Erofeeva ${ }^{b}$, \\ A.V. Lyovina ${ }^{a}$, N.I. Zaviyalova ${ }^{a}$ \\ aSC MBSPC "Cytomed”, St. Petersburg, Russian Federation \\ ${ }^{b}$ Smorodintsev Research Institute of Influenza, St. Petersburg, Russian Federation \\ ${ }^{c}$ Implicit Bioscience Ltd, Brisbane, Australia
}

\begin{abstract}
Aim. To compare the safety and prophylactic efficacy of Cytovir-3 and Arbidol in an open-label randomized clinical trial in children at seasonal risk of infectious respiratory disease. Methods. This study was performed in the period preceding a seasonal outbreak of acute respiratory viral infections (ARVI) and influenza. The study enrolled apparently healthy children aged 6 to 18 years without contra-indications to either Cytovir-3 or Arbidol. Cytovir-3 was given as 1 capsule per day, each day in a fasted state for 12 days. Arbidol was taken as a $100 \mathrm{mg}$ capsule twice a week for three weeks. Following dosing, subjects were followed-up for a further three weeks. Overall health and presence of clinical symptoms of either ARVI or influenza were monitored daily in all subjects. The level of sIgA in saliva was baselined before treatment and measured at the end of the follow-up period. Results. Most subjects did not exhibit any change in overall health status during the dosing and follow-up periods. The first two cases of illness in subjects receiving Cytovir-3 were diagnosed at the end of the third week after completion of dosing. In those subjects receiving Arbidol the first cases of illness were reported at the end of the second week following the end of prophylactic dosing. All patients displayed a significant increase in sIgA level at the end of the dosing period, but this was more pronounced in the Cytovir-3 group. Conclusion. The results of the open comparative randomized study drugs Cytovir-3 and Arbidol confirmed the safety and tolerability of both medications, and that the prophylactic efficacy of Cytovir-3 is equal to that of Arbidol.
\end{abstract}

Key words: ARVI, prophylaxis, preventive medication, children, Cytovir-3, Arbidol, sIgA.

\section{ОТКРЫТОЕ СРАВНИТЕЛЬНОЕ ИССЛЕДОВАНИЕ БЕЗОПАСНОСТИ И ЭФФЕКТИВНОСТИ ПРЕПАРАТОВ «ЦИТОВИР-З" И «АРБИДОЛ" ПРИ ПРОФИЛАКТИКЕ ДЕТЕЙ В ПЕРИОД СЕЗОННОГО ПОДЪЕМА ЗАБОЛЕВАЕМОСТИ РЕСПИРАТОРНЫМИ ВИРУСНЫМИ ИНФЕКЦИЯМИ

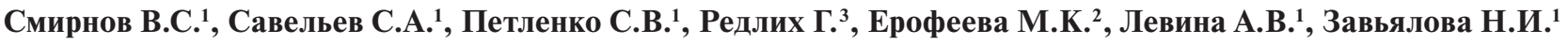 ${ }^{1}$ АО Медико-биологический научно-производственный комплекс «Цитомед», Санкт-Петербург, Россия ${ }^{2}$ ФГБУ НИИ гриппа им. Смородинцева, Санкт-Петербург, Россия \\ ${ }^{3}$ Implicit Bioscience, Woolloongabba, Brisbane, Australia}

Резюме. Цель исследования: открытое сравнительное, рандомизированное исследование профилактической эффективности препаратов Цитовир-3 и Арбидол. Методы. Исследование проведено в период, предшествовавший

\section{Адрес для переписки: \\ Смирнов Вячеслав Сергеевич \\ 191023, Россия, Санкт-Петербург, Мучной пер., 2, АО МБНПК «Цитомед». \\ Тел.: 8 (911) 948-59-22 (моб.). E-mail: vssmi@mail.ru}

Библиографическое описание:

Смирнов В.С., Савельев С.А., Петленко С.В., Редлих Г., Ерофеева М.К.,

Левина А.В., Завьялова Н.И. Открытое сравнительное исследование

безопасности и эффективности препаратов «Цитовир-3» и «Арбидол» при профилактике детей в период сезонного подъема заболеваемости респиторными вирусными инфекциями // Инфекция и иммунитет. 2019

T. 9, № 2. C. 273-278. doi: 10.15789/2220-7619-2019-2-273-278

(c) Smirnov V.S. et al., 2019
Contacts:

Vyacheslav S. Smirnov

191023, Russian Federation, St. Petersburg, Muchnoy lane, 19 JSC MBSPC "Cytomed".

Phone: +7 (911) 948-59-22 (mobile). E-mail: vssmi@mail.ru

Citation:

Smirnov V.S., Savelyev S.A., Petlenko S.V., Redlich G., Erofeeva M.K., Lyovina A.V., Zaviyalova N.I. Comparative efficacy and safety of preventive treatment with cytovir-3 and arbidol in children during seasonal outbreak of respiratory viral infection (an open-label randomized clinical study) // Russian Journal of Infection and Immunity = Infektsiya i immunitet, 2019, vol. 9, no. 2, pp. 273-278. doi: 10.15789/2220-7619-2019-2-273-278

DOI: http://dx.doi.org/10.15789/2220-7619-2019-2-273-278 
сезонной вспышке острых респираторных вирусных инфекций и гриппа. В исследовании принимали участие практически здоровые дети в возрасте от 6 до 18 лет, не имевшие противопоказаний к назначению препаратов Цитовир-3 и Арбидол. Цитовир-3 назначали по 1 капсуле натощак 1 раз в день ежедневно в течение 12 дней. Арбидол применяли по 100 мг 2 раза в неделю в течение 3 недель. По окончании периода профилактики детей наблюдали еще 3 недели. Ежедневно у всех участников выявляли общее состояние и наличие клинических симптомов ОРВИ или гриппа. В начале и в конце срока наблюдения у всех добровольцев определяли уровень sIgA в слюне. Результаты. В период проведения профилактического приема препаратов и последующего наблюдения у большинства добровольцев не выявлено каких-либо отклонений в состоянии здоровья. Первые 2 случая заболевания у лиц, получавших Цитовир-3, отмечены в конце 3 недели после профилактического приема препарата. У лиц, получавших Арбидол первые заболевания отмечены в конце 2 недели после окончания курса профилактического приема препарата. В конце периода профилактики у всех добровольцев выявлен достоверный рост уровня sIgA, более выраженный у детей, принимавших Цитовир-3. Заключение. Полученные результаты открытого сравнительного рандомизированного исследования безопасности и эффективности препаратов Цитовир-3 и Арбидол, показали, что препарат Цитовир-3 по своей профилактической эффективности, как минимум, не уступает препарату Арбидол.

Ключевые слова: ОРВИ, заболеваемость респираторными инфекциями, профилактика, дети, Цитовир-3, Арбидол, иммуноглобулин А.

Influenza and other acute respiratory viral infections (ARVI) are the most common seasonal epidemic diseases in human populations. According to WHO, influenza viruses result in 250000 to 500000 deaths annually. For example, in 2014 least 5 million cases of severe diseases were recorded [1].

Official statistics for the Russian Federation show that between 0.9 and 3.5 million cases of influenza are registered yearly, resulting in 20000 to 53000 deaths.

Children are considered to be most at risk, particularly those who spend most of their time in crowded group spaces such as kindergartens, schools, boarding schools, cadet corps etc. The development of safe and effective drug interventions to reduce the impact of respiratory viral pathogens in such groups of children that are often in close body contact is of great practical importance. Interventions intended to prevent influenza and ARVI may be grouped into one of three main categories: (i) pathogen-specific, prophylactic interventions (e.g. vaccines), (ii) disease-specific antiviral drugs, or (iii) non-specific, host-directed interventions (e.g. interferons, inducers of endogenous interferon synthesis, immunotropic therapy, multivitamin and mineral preparations, antioxidants etc.).

There are a number of influenza vaccines available in the Russian Federation, Grippol being the most widely used [2]. Among the antiviral drugs, the M2 channel inhibitors (amantadin, remantadin) [3] and neuraminidase inhibitors (oseltamivir, zanamivir) [4] are the most common. The latter two are recognized by the WHO as a standard therapy for influenza [5].

Non-specific, host-directed drugs to treat and prevent influenza and ARVI include numerous interferon-based drugs, derivatives of acridonacetic acid and symptomatic medications (quick-relief medication) [6]. This class includes the two drugs compared in this study: Cytovir-3 and Arbidol. Cytovir-3 is a mixture of ascorbic acid, bendazol and the dipeptide GlutamylTryptophan in a form of a sodium salt [6]. Arbidol (umifenovir) is recognized as a drug with direct antiviral as well as immunotherapeutic properties and is used for prevention and treatment of influenza and ARVI. For non-specific prevention during influenza and ARVI outbreaks this drug is prescribed for children aged 6 to 12 years as $100 \mathrm{mg}$ and for children over 12 year and for adults as $200 \mathrm{mg}$ twice a week over three weeks of treatment [7].

Cytovir-3 is widely used for prevention and early treatment of influenza and other ARVI in children and adults [6, 8]. Initially this drug was dosed with the same regimen for both prophylactic and therapeutic use (one capsule three times a day, over four consecutive days) [6]. However the concept of "prevention" was later subcategorized to separate the use for routine or seasonal prevention from that where urgent prevention was required. The former aims to support background capacity in the innate immune response to an epidemic rise in morbidity whereas the latter is preferred in a situation where the subject has current contact with persons who are definitely unwell, but not yet specifically symptomatic for ARVI or influenza. From this perspective, it is logical to assume that these two regimens should differ both in duration and dosing of Cytovir-3. The regimen for urgent prevention has remained unchanged, but routine seasonal prevention is now dosed at one capsule per day, in a fasting state, for 12 consecutive days.

The current study was devoted to investigation of the preventive efficacy of this prolonged regimen for routine prevention. The main goal was to assess the preventive efficacy of a prolonged regimen of Cytovir-3 compared to standard regimen of Arbidol in children during a seasonal outbreak of influenza and ARVI. This clinical trial was prospective and performed as open-label randomized comparative parallel study of efficacy and safety of Cytovir-3 (capsules) and Arbidol (capsules $100 \mathrm{mg}$ ) as routine prophylaxis of influenza and ARVI in children in pre-school and secondary school organizations.

\section{Materials and methods}

The current study enrolled 207 healthy children aged 6 to 18 years (boys: 119 or $57.4 \%$; girls: 88 or $42.63 \%$ ) attending childcare facilities in pre-schools or secondary schools and who matched the inclusion criteria. Two commercially available drugs with proven 
efficacy in the treatment and prevention of influenza and ARVI were used: Cytovir-3 capsules (Cytomed Oy, Lappeenranta, Finland) and Arbidol capsules 100 mg (JSC Pharmstandard-Leksredstva, Kursk, Russian Federation) [6, 11].

Study recruitment was voluntary. Before randomization to a treatment group, written informed consent was obtained from a subject's parents or adoptive parents or other legal representative. Additional written informed consent was obtained from all subjects over the age of 14 years. Racial and ethnic differences were disregarded. 102 children were randomized to receive Cytovir-3 and 105 children were randomized to receive Arbidol. Both legislation of the Russian Federation and the Declaration of Helsinki (rev.7, 2013) declare the use of placebo controls illegal and unethical in such clinical trials. Mean age of children included into the trial was 8.2 years (8.7 in the Cytovir-3 group and 7.6 in the Arbidol group, $p>0.1)$. Neither gender differences nor structure of anamnestic morbidity were statistically significant $(p=0.46-1.0)$. Inclusion criteria were: boys and girls aged from 6 to 18 years without any signs of infection or intoxication, with a verified diagnosis "free of disease" (according to the decision of Ministry of Health No. 621 dd 30.12.2003 classified as health group I or II), not having taken antibiotic, antiviral, hormonal or immunotropic drugs during the previous two months and not being vaccinated against influenza during the 12 preceding months. Teenage girls were required to have negative pregnancy test.

Exclusion criteria were: lack of tolerability of investigated drugs (or their separate compounds), having contacts with ARVI patients during preceding 14 days, participation in any other clinical trial during preceding 30 days. Children of staff of either research center or a sponsor company were excluded from the trial.

Cytovir-3 was prescribed to children included in the experimental group as follows: 1 capsule taken 30 minutes before a meal once per day for 12 consecutive days; Arbidol was prescribed to children included in the comparison group as follows: 1 capsule $(100 \mathrm{mg})$ twice a week for three weeks. Since the dosing duration for each of the two drugs was different, the study duration was different for each group. Inclusive of the 3 -week follow-up, the Cytovir-3 group took from 33 to 35 days to complete the study and the Arbidol group took from 39 to 42 days to do so.

During the entire period of observation, children were examined daily and their general health status as well as skin, mucosa, peripheral lymph nodes was noted. Any apparent illness was assessed for conformity to ARVI symptoms. In addition, all study participants were checked daily for the presence of adverse events and lack of drug tolerability. Body temperature, heart rate, blood pressure and breathing rate were assessed on days 1, 3, 5, 7, 9 and 11 in the Cytovir-3 group and on days $1,4,8,11,15$ and 18 in the Arbidol group.

On the first and last days of taking Cytovir-3 and Arbidol (day 12 and 18, respectively) the level of secretory immunoglobulin A (sIgA) was assessed. For this purpose saliva samples were taken from all partici- pants and placed into the Sali Caps containers (IBL International, Italy) made of extra pure polypropylene (absorptive capacity less than 5\%) and equipped with a tubule preventing contact of saliva with skin and labial mucosa. The sIgA determination was performed by means of quantitative ELISA method using a StatFax 2100 analyzer (Becton Dickinson, USA) with a wavelength 450 and $620 \mathrm{~nm}$ and commercial kits (Dia Metra, Germany) in accordance with protocols of the manufacturer. The measured range was $0.5-400 \mu \mathrm{g} / \mathrm{mL}$, method sensitivity $-0.5 \mu \mathrm{g} / \mathrm{mL}$. All data were entered on individual case report forms.

Data were analyzed using IBM SPSS Statistics for Windows, version 22.0. (Armonk, NY: IBM Corp.). The between-group comparisons were assessed using paired and unpaired t-test for normally distributed data (Lilliefors test). For the data failed normality test a pairwise Wilcoxon signed-rank test (for dependent samples) and Mann-Whitney U test (for independent samples) were used. Differences between groups were considered as significant if $p \leq 0.05$. Anamnestic morbidity was assessed using a chi-square test. In some cases Yates's correction for continuity and Fisher's exact test were used [9]. Data were expressed as $\mathrm{M} \pm \mathrm{SE}$.

\section{Results}

The initial health status of all participants was estimated as normal. Arterial blood pressure was $108.3 \pm 7.8 / 67.2 \pm 5.0 \mathrm{~mm} \mathrm{Hg}$ in the Cytovir-3 group and $104.6 \pm 9.8 / 65.6 \pm 5.7 \mathrm{~mm} \mathrm{Hg}$ in the Arbidol group. There were no significant differences in heart rate between Cytovir-3 and Arbidol groups (81.9 \pm 6.0 and $81.7 \pm 7.8$, respectively) and body temperature $\left(36.3 \pm 0.2^{\circ} \mathrm{C}\right.$ and $36.4 \pm 0.2^{\circ} \mathrm{C}$, respectively). Prior medical histories of ARVI (100\% in both groups), chicken pox ( $26.0 \%$ and $29.8 \%$, respectively, $\mathrm{p}=0.54)$, tonsillitis ( $7.7 \%$ and $5.8 \%$ respectively, $p=0.54)$ and acute bronchitis $(7.7 \%$ and $8.6 \%$ respectively, $p=0.8)$ were the most common. Other diseases (otitis, adenoiditis, scarlet fever, pneumonia etc.) were sporadic. Regardless the etiology, all reported diseases had fully resolved no later than two months prior to enrolment in this clinical trial.

Before the trial all participants underwent a determination of salivary $\operatorname{sIgA}$, the level of which was $60.35 \pm 15.1 \mathrm{mg} / \mathrm{ml}$ in the Cytovir-3 group and $66.83 \pm 22.5 \mathrm{mg} / \mathrm{ml}$ in the Arbidol group.

During the period of treatment no cases of ARVI were reported despite overall increased level of respiratory illness among the general pediatric population. During follow-up period 9 children were diagnosed with ARVI (tabl. 1).

As noted in table 1, the number of cases among children who received Cytovir-3 was 3,5 times less than among those who received Arbidol. This is an evidence of a consistent trend towards a lower morbidity in the Cytovir-3 group.

An analysis of the morbidity rate (qualitative indicators [10]) did not reveal any significant differences $(\mathrm{d}=5.6 ; \Delta=6.7-1.9=4.8 ; 5.6>4.74)$. The same re- 
Table 1. ARVI incidence rate in children during follow-up period

\begin{tabular}{|c|c|c|c|}
\hline \multirow{2}{*}{ Groups } & \multicolumn{2}{|c|}{ Parameters of ARVI morbidity } & \multirow{2}{*}{ Significance of differences } \\
\cline { 2 - 3 } & Number of cases & ARVI affected, \% & \\
\hline Cytovir-3 group $(n=102)$ & 2 & 1.9 & \multirow{2}{*}{0.1} \\
\hline Arbidol group $(n=105)$ & 7 & 6.7 & \\
\hline
\end{tabular}

sults were obtained when Fisher's exact test was used [9], showing that the true value of differences in the proportions of positive diagnosis is between -0.5 and 10.5. Since the calculated confidence limit includes the zero in expression $\mathrm{p}=0.05$, it is possible to conclude that the resulting differences in the respiratory morbidity rates between groups are not statistically significant. That is to say, in terms of preventive treatment both drugs are equally effective.

The analysis of efficacy of preventive treatment in each group included calculation of the relative morbidity rate (RMR), which was found to be 0.0196 $(2 / 102)$ in the Cytovir-3 group and $0.066(7 / 105)$ in the Arbidol group. It follows that the percentage of protected people in each group is $1-\mathrm{RMR}$ or $1-0.0196=$ 0.980 for the Cytovir-3 group and $1-0.66=0.934$ for the Arbidol group. Thus protection index is calculated as $0.980 / 0.934=1.049$, i.e. Cytovir-3 protected children 1.049 times better than Arbidol. This result reflects the prophylactic ability of these two drugs.

Another perspective on preventive efficacy is the period of retention of accumulated protection from disease, defined as the duration from the onset of treatment to the first clinical symptoms and its dynamics in study participants who became sick (tabl. 2).

These data show that no subject in either treatment arm was diagnosed with ARVI or influenza during the respective dosing periods. Moreover there were no incidences of illness during first week of observation period after dosing. However during the second week, signs of respiratory disease were reported in three participants from the Arbidol group but none in the Cytovir-3 group. During the third and final week, in the Arbidol group four subjects had a positive diagnosis but only two were diagnosed in the Cytovir-3 group. These results suggest that the duration of protection is three weeks for Cytovir-3 but only two weeks for Arbidol. Given the small sample size (slightly more than 100 subjects in each group) these results are still preliminary and further investigation is needed.

Besides epidemiological parameters (tables 1 and 2), salivary sIgA titres were assessed before and after dosing in each group, i.e. on day 12 in the Cytovir-3 group and on day 18 in the Arbidol group (tabl. 3).

The sIgA is the most active part of local immune response of mucosa, which is an entry point for various infections. The salivary sIgA reflects the preventive efficacy of antiviral drugs taken by the host. The current results suggest that baseline levels of sIgA in each group were similar to each other and there were no significant intergroup differences. After dosing, a marked increase of sIgA was revealed suggesting a significant rise of local immunity in mucosa. Intergroup differences in this case were not statistically significant $(\mathrm{p}>$ $0.05)$. It is worth mentioning that a slightly increased baseline sIgA level was observed in the Arbidol group when compared with the Cytovir-3 group. However after dosing with Arbidol, sIgA levels were lower than those in children receiving Cytovir-3. For example sIgA titres increased by 1.28 fold in the Arbidol group and 1.46 fold in the Cytovir-3 group. The greater augmentation of sIgA titres in the Cytovir-3 group may suggest a higher preventive efficacy of Cytovir-3.

\section{Discussion}

ARVI prophylaxis continues to be a real problem for public health, despite significant progress in the development of antiviral therapy. For a preventive treatment of ARVI and influenza to be effective, it should at least significantly minimize the incidence and severity of complications, if not actually result in the termination of an epidemic. Initially great hope was placed on wider application of preventive vaccination. However this approach is effective only when vaccination coverage reaches $70 \%$, a goal that is achievable only in a limited number of highly organized groups, for example military units [11]. According to epidemiological studies, normal vaccination coverage reaches only $20-30 \%$ of the population [12].

One solution to this problem is the use of effective prophylactic drugs to reduce the spread of 'flu and other ARVI, especially in cases where vaccination is undesirable and/or impractical [13]. Arbidol is used quite widely in the Russian Federation [7]. According to Shumilov and co-authors (2002) Arbidol's preventive efficiency is $25 \%$ and its therapeutic efficacy is 1.33 [11]. The authors believe that Arbidol reduces the number of ARVI cases, diminishes duration of fever and decreases severity of intoxication and respiratory tract destruction. Another drug for prevention and treatment influenza and ARVI is Cytovir-3. This drug

Table 2. ARVI and influenza incidence rate in children during entire clinical trial

\begin{tabular}{|c|c|c|c|c|c|}
\hline \multirow{3}{*}{ Study group } & \multicolumn{5}{|c|}{ Number of affected children with influenza and ARVI (n/\%) } \\
\hline & \multirow{2}{*}{ Onset } & \multirow{2}{*}{ During dosing } & \multicolumn{3}{|c|}{ During follow-up period } \\
\hline & & & Week 1 & Week 2 & Week 3 \\
\hline Cytovir-3 & $0 / 0$ & $0 / 0$ & $0 / 0$ & $0 / 0$ & $2 / 1.6^{*}$ \\
\hline Arbidol & $0 / 0$ & $0 / 0$ & $0 / 0$ & $3 / 2.9$ & $4 / 3.8$ \\
\hline
\end{tabular}

Notes. $\mathrm{n}$ - number of children; * - children got sick in the last 2 days of the third week. 
Table 3. Changes in sIgA titres before and after dosing with investigated drugs

\begin{tabular}{|c|c|c|c|}
\hline \multirow{2}{*}{ Study Group } & \multicolumn{2}{|c|}{ slgA concentration, $\mathbf{m c g} / \mathbf{m l}$} & \multirow{2}{*}{ Increment ratio, slgA } \\
\cline { 2 - 3 } & Before dosing & After dosing & 1.47 \\
\hline Cytovir-3 $(\mathrm{n}=102)$ & $60.40 \pm 1.47$ & $88.63 \pm 2.11^{\star}$ & 1.28 \\
\hline Arbidol $(\mathrm{n}=105)$ & $66.84 \pm 2.17$ & $85.74 \pm 2.36^{\star}$ & \\
\hline
\end{tabular}

Note. *Significant differences as compared to data before dosing $(p<0.002)$.

is a pharmaceutical composition consisting of ascorbic acid, bendazole and glutamyl-tryptophan at a ratio of 50:20:0.5 [14]. There is evidence that Cytovir-3 is an effective mean of urgent prevention (1 single dose 3 times a day during 4 days) and decreases ARVI and influenza morbidity by $1.96-4.91$ fold [6]. This example relates to cases when contact between the pathogens and the susceptible host has already occurred, but the clinical infection is yet to manifest. However the other type of prevention therapy, namely routine or scheduled prevention, is no less important. Routine prevention takes place in the period preceding seasonal or epidemic outbreaks of influenza and other ARVI. This kind of prevention aims to reduce disease incidence (including through implicit seroconversion) and to create a virtual immunity, likely due to latent viruses failing to manifest clinically [15].

This study investigated the efficacy of such an approach. It was performed in healthy children during the period preceding a seasonal outbreak of ARVI. The primary endpoint was comparison of the efficacy of two widely-used drugs - Arbidol and Cytovir-3. We hypothesized that increasing the duration of the preventive dosing regimen of Cytovir-3 from 4 to 12 days while simultaneously reducing daily dose from 3 to 1 capsule would achieve the desired preventive efficacy in this population.

The results show that comparable courses of $\mathrm{Cy}-$ tovir-3 and Arbidol in this setting were completely safe and well tolerated. During the dosing periods, no ARVI incidence was reported in either group, and during the follow-up period only sporadic incidences of illness were noted. Among children receiving Cytovir-3 two such cases $(1.6 \%)$ were reported in the last two days of the third week of follow-up (tabl. 3). The morbidity in children receiving Arbidol was slightly higher $-7(6.7 \%)$, moreover the first three cases of illness in the Arbidol group were reported as early as the second week of follow-up. At a first glance this difference seems to be significant, however statistical analysis did not reveal significance between comparative groups, probably due to the small sample size. Nevertheless it could be argued that the duration of preventive efficacy of Arbidol is about two weeks whereas with Cytovir-3 it is up to three weeks even with a 3 -fold reduction of the normal daily dose. This reduced dosing regimen for Cytovir-3 is comparable to the standard preventive and therapeutic regimen for Arbidol.

One important factor in resistance to viral infection is the level of sIgA in saliva, a biomarker of innate immunity. More than $75 \%$ of all infections including myxoviruses enter our body through the mucous membranes [16]. Therefore it is important to measure sIgA levels during preventive treatment to understand the resilience of mucosal immunity. The study shows that dosing of Cytovir-3 induces a significant increase of sIgA titres in saliva (1.47 fold on average). The same effect was noted during Arbidol dosing, but to a lesser extent - only 1.28 fold. And while sIgA levels at the end of dosing were not statistically different between the groups, baseline sIgA levels in subjects randomized to receive Arbidol were higher than in those subjects who received Cytovir-3. This suggests a trend towards more active enhancement of innate immunity level in the mucosa of children receiving Cytovir-3 which supports the observation that subjects received Cytovir-3 had longer protection than those who received Arbidol (tabl. 2).

\section{Conclusion}

In this setting of routine seasonal prophylaxis of ARVI and influenza among infants in close-contact groups, the majority of investigated parameters were not statistically different between subjects receiving either Cytovir-3 or Arbidol. This supports the conclusion that the preventive efficacy of Cytovir-3 is comparable to that of Arbidol. In some cases Cytovir-3 displayed a more pronounced, though not statistically significant, efficacy.

Further studies using larger sample sizes are needed to confirm in greater detail the preventive efficacy of these drugs, but these results suggest that, despite both investigated drugs being equal in terms of preventive efficacy, Cytovir-3 is slightly more effective.

\section{Список литературы/References}

1. Ельшина Г.А., Харит С.М., Романенко В.В., Комлева С.В., Пучкова Н.Г., Чирун Н.В., Абрамова М.А., Лонская Н.И., Горбунов М.А. Результаты изучения безопасности и иммуногенности отечественных субъединичных адъювантных пандемических моновакцин группы гриппол ${ }^{\circledR}$ у детей от 6 месяцев до 17 лет // Эпидемиология и вакцинорофилактика. 2011. № 2 (57). C. 41-46. [Yelshina G.A., Kharit S.M., Romanenko V.V., Komleva S.V., Puchkova N.G., Chirun N.V., Abramova M.A., Lonskaya N.I., Gorbunov M.A. Results of the study of safety and immunogenicity of domestic subjective adjuvant pandemic monopuchin group of grippol ${ }^{\circledR}$ in children from 6 months to 17 years. Epidemiologiya $i$ vaktsinorofilaktika $=$ Epidemiology and Vaccinal Prevention, 2011, no. 2(57), pp. 41-46. (In Russ.)] 
2. Кузьменко Л.Г., Котлуков В.К., Антипова Н.В. Современные возможности применения комбинированныхпрепаратов для лечения острых респираторных инфекций у детей // Педиатрия. 2013. T. 92, № 4. C. 71-76. [Kuzmenko L.G., Kotlukov V.K., Antipova N.V. Modern possibilities of application of combined preparations for treatment of acute respiratory infections in children. Pediatriya $=$ Pediatrics, 2013, vol. 92, no. 4, pp. 71-76. (In Russ.)]

3. Сепетлиев Д. Статистические методы в научных медицинских исследованиях. М.: Медицина, 1968. 207 c. [Sepetliev D. Statistical methods in scientific medical research. Moscow: Medicine, 1968. 207 p. (In Russ.)]

4. Смирнов В.С. Профилактика и лечение гриппа и острых респираторных вирусных инфекций. СПб.: ФАРМиндекс, 2008. 50 c. [Smirnov V.S. Prevention and treatment of influenza and acute respiratory viral infections. St. Petersburg: PHARMindex, 2008. 50 p. (In Russ.)]

5. Смирнов В.С., Куликов С.В., Власов В.Ю. Фармацевтическая композиция для лечения вирусных заболеваний. Патент № 2155254, 2001. [Smirnov V.S., Kulikov S.V., Vlasov V.Yu. Pharmaceutical composition for the treatment of viral diseases. Patent No. 2155254, 2001]

6. Смирнов В.С., Селиванов А.А. Биорегуляторы а профилактике и лечении гриппа. СПб.: Наука, 1996. 69 c. [Smirnov V.S., Selivanov A.A. Bioregulators and prevention and treatment of influenza. St. Petersburg: Nauka, 1996. 69 p. (In Russ.)]

7. Шумилов В.И., Шустер А.М., Лобастов С.П., Шевцов В.А., Медников Б.Л., Пилавский С.А., Литус В.И. Эффективность арбидола в профилактике и лечении острых респираторных вирусных инфекций у военнослужащих // Военномедицинский журнал. 2002. T. 323, № 9. C. 51-53. [Shumilov V.I., Shuster A.M., Lobastov S.P., Shevtsov V.A., Mednikov B.L., Pilavskii S.A., Litus V.I. Efficacy of arbidol in prophylaxis and treatment of acute respiratory viral infections in servicemen. Voenno-meditsinskiy zhurnal = Military Medical Journal, 2002, vol. 323, no. 9, pp. 51-53. (In Russ.)]

8. Alves Galvão M.G., Rocha Crispino Santos M.A., Alves da Cunha A.J. Amantadine and rimantadine for influenza A in children and the elderly. Cochrane Database Syst. Rev., 2014, iss. 11: CD002745. doi: 10.1002/14651858.CD002745.pub4

9. Bergmeier L.A., Wang Y., Lehner T. The role of immunity in protection from mucosal SIV infection in macaques. Oral Dis., 2002 , vol. 8, suppl. 2, pp. 63-68.

10. Blaising J., Polyak S.J., Pécheur E.I. Arbidol as a broad-spectrum antiviral: an update. Antiviral Res., 2014, vol. 107, pp. 84-94. doi: 10.1016/j.antiviral.2014.04.006

11. De Clercq E., Li G. Approved antiviral drugs over the past 50 years. Clin. Microbiol. Rev., 2016, vol. 29, pp. 695-747. doi:10.1128/ CMR.00102-15.

12. Doll M.K., Winters N., Boikos C., Kraicer-Melamed H., Gore G., Quach C. Safety and effectiveness of neuraminidase inhibitors for influenza treatment, prophylaxis, and outbreak control: a systematic review of systematic reviews and/or meta-analyses. J. Antimicrob. Chemother., 2017, vol. 72, no. 11, pp. 2990-3007. doi: 10.1093/jac/dkx271

13. Executive summary of the $6^{\text {th }}$ meeting of the WHO Expert Working Group of the GISRS for Surveillance of Antiviral Susceptibility. Wkly Epidemiol. Rec., 2017, vol. 92, no. 41, pp. 611-612.

14. Fisher R.A. Statistical methods for research workers. 14 ${ }^{\text {th }}$ edition. Edinburgh: Oliver\& Boid, 1970. $362 p$.

15. Jiménez-García R., Hernandez-Barrera V., Rodríguez-Rieiro C., Carrasco Garrido P., López de Andres A., Jimenez-Trujillo I., Esteban-Vasallo M.D., Domínguez-Berjón M.F., Miguel-Diez J., Astray-Mochales J. Comparison of self-report influenzavaccination coverage with data from a population based computerized vaccination registry and factors associated with discordance. Vaccine, 2014, vol. 32, no. 35, pp. 4386-4392. doi: 10.1016/j.vaccine.2014.06.074

16. Rainwater-Lovett K., Chun K., Lessler J. Influenza outbreak control practices and the effectiveness of interventions in long-term care facilities: a systematic review. Influenza Other Respir. Viruses, 2014, vol. 8, no. 1, pp. 74-82. doi:10.1111/irv.12203

\author{
Авторы: \\ Смирнов В.С., д.м.н., профессор, главный научный сотрудник \\ АО МБНПК «Цитомед», Санкт-Петербург, Россия; \\ Савельев С.А., к.б.н., сотрудник отдела регистрации \\ АО МБНПК «Цитомед», Санкт-Петербург, Россия; \\ Петленко С.В., д.м.н., начальник клинического отдела \\ АО МБНПК «Цитомед», Санкт-Петербург, Россия; \\ Редлих Г., генеральный и исполнительный директор компании \\ «Имплисит Биосайнс», Брисбен, Австралия; \\ Ерофеева М.К., д.м.н., зав. лабораторией испытаний новых \\ средств защиты от вирусных инфекций ФГБУ НИИ гриппа \\ им. А.А. Смородинцева МЗ РФ, Санкт-Петербург, Россия; \\ Левина А.В., сотрудник отдела клинических исследований \\ АО МБНПК «Цитомед», Санкт-Петербург, Россия; \\ Завьялова Н.И., сотрудник отдела клинических исследований \\ АО МБНПК «Цитомед», Санкт-Петербург, Россия.
}

\section{Authors:}

Smirnov V.S., PhD, MD (Medicine), Professor, Head Researcher, JSC MBSPC "Cytomed", St. Petersburg, Russian Federation;

Savelyev S.A., PhD (Biology), Officer of the Registration Department, JSC MBSPC "Cytomed", St. Petersburg, Russian Federation;

Petlenko S.V., PhD, MD (Medicine), Head of Clinical Department, JSC MBSPC "Cytomed", St. Petersburg, Russian Federation; Redlich G., Chief Executive Officer \& Managing Director, "Implicit Bioscience Ltd", Brisbane, Australia;

Erofeeva M.K., PhD, MD (Medicine), Head of the Laboratory for Testing New Means for Protection Against Viral Infections, Smorodintsev Research Institute of Influenza, St. Petersburg, Russian Federation;

Lyovina A.V., Officer of Clinical Department of JSC MBSPC

"Cytomed", St. Petersburg, Russian Federation;

Zaviyalova N.I., Officer of Clinical Department of JSC MBSPC

"Cytomed", St. Petersburg, Russian Federation.

Received 16.05.2018

Revision received 11.03.2019

Accepted 18.03.2019 